\title{
Effects of Haloperidol on Delirium in Adult Patients: A Systematic Review and Meta-Analysis
}

\author{
Ying-zi Shen Ke Peng Juan Zhang Xiao-wen Meng Fu-hai Ji \\ Department of Anesthesiology, First Affiliated Hospital of Soochow University, Suzhou, China
}

\section{Significance of the Study}

- This study assessed the effects of haloperidol for prevention and treatment of delirium in adult patients. Haloperidol prophylaxis with a dose of $\geq 5 \mathrm{mg}$ /day might help reduce the incidence of delirium in surgical patients. Haloperidol exhibited similar effects as the second-generation antipsychotics. However, the current evidence is based on a small patient population, and further studies with larger sample sizes are required.

\section{Keywords}

Haloperidol · Delirium · Antipsychotics

\begin{abstract}
Objective: The aim of this systematic review and meta-analysis was to investigate whether or not the use of haloperidol could reduce the incidence of delirium in adult patients. Subjects and Methods: PubMed, Embase, the Cochrane Library, Elsevier, Wiley, and Ovid were searched for randomized controlled trials and prospective interventional cohort studies that compared haloperidol with placebo for delirium prophylaxis or with second generation antipsychotics for delirium treatment. The primary end point was the incidence and severity of delirium. After reviewing 272 relevant articles, 10 studies with 1,861 patients were finally included (haloperidol vs. placebo in 8 studies [ $n=1,734]$, and haloperidol vs. second-generation antipsychotics in 2 studies [ $n=127]$ ).
\end{abstract}

Revman 5.3 was used for the data analysis. Results: Compared with placebo, a high dose of prophylactic haloperidol ( $\geq 5 \mathrm{mg} /$ day) may help reduce the incidence of delirium in surgical patients (risk ratio $0.50,95 \% \mathrm{Cl} 0.32,0.79$ ). There were no differences in the duration of delirium, QTc interval prolongation, extrapyramidal symptoms, intensive care unit stay, hospital stay, or mortality between the haloperidol and placebo groups. For delirium treatment, haloperidol exhibited similar effects as the second-generation antipsychotics. Conclusions: In this study, the limited available data revealed that prophylaxis haloperidol at a dose of $\geq 5 \mathrm{mg} /$ day might help reduce delirium in adult surgical patients. Further outcome studies with larger sample sizes are required to confirm these findings.

(c) 2018 The Author(s) Published by S. Karger AG, Basel

Y.S. and K.P. contributed equally to this study.

\section{KARGER}

E-Mail karger@karger.com www.karger.com/mpp (c) 2018 The Author(s) Published by S. Karger AG, Basel

Karger Open access

This is an Open Access article licensed under the Creative Commons Attribution-NonCommercial-4.0 International License (CC BY-NC) (http://www.karger.com/Services/OpenAccessLicense), applicable to the online version of the article only. Usage and distribution for commercial purposes requires written permission.
Fu-hai Ji, MD

Department of Anesthesiology, First Affiliated Hospital of Soochow University 188 Shizi Street

Suzhou, Jiangsu 215006 (China)

E-Mail jifuhaisuda@163.com 


\section{Introduction}

Delirium is a neuropsychiatric disorder characterized by an acute onset of confusion and alterations of consciousness $[1,2]$, resulting in increased complications, prolonged hospitalization, and worse outcomes [3-5]. The incidence of delirium ranges from 29 to $64 \%$ in medical in-patients $[3,4]$ and even higher in intensive and palliative care settings [5]. The risk factors include elderly patients, cognitive impairment, prior delirium, abnormal sodium, potassium or glucose, preoperative narcotics, tobacco or psychotropic drug use, apolipoprotein $\mathrm{E} 4$ carrier status, and postoperative hypotension [6-11].

Haloperidol, a typical antipsychotic, is still used widely to treat delirium. However, the results from previous studies are inconsistent. Several studies reported that the use of haloperidol was associated with a decrease in delirium incidence [12-15], while others did not report a beneficial effect of haloperidol [16-19]. It was also reported that prophylactic low-dose haloperidol did not reduce the incidence of delirium $[20,21]$.

Recently, 2 reviews showed promising results on haloperidol for delirium management, but they failed to summarize the evidence by means of a quantitative metaanalysis [22, 23]. Hence, a systematic review and metaanalysis were designed to assess the effects of haloperidol for the prevention and treatment of delirium in adult patients.

\section{Materials and Methods}

\section{Literature Search}

Two researchers (Y.S. and K.P.) independently performed a comprehensive literature search to identify trials that compared the effects of haloperidol with placebo or antipsychotics on the outcomes of delirium in adult patients. PubMed, Embase, the Cochrane Library, Elsevier, Wiley, and Ovid were searched until May 1, 2017. A basic search was performed using medical subject headings and free text words: "haloperidol," "antipsychotics," and "delirium." No language or publication date restriction was applied. In addition, references and previous reviews were manually checked for other potentially eligible trials. Any disagreement at any stage of this study was resolved by group discussion and consensus.

The inclusion criteria were adult patients, haloperidol prophylaxis or treatment, comparisons of haloperidol with placebo or second-generation antipsychotics, delirium-related outcomes, randomized controlled trials (RCTs), and prospective interventional cohort trials. The search flow diagram is shown in Figure 1. A total of 272 articles relevant to the search terms were identified, and 10 studies were finally included in this study.
272 records identified by database search Embase $(n=152) \quad$ PubMed $(n=97)$ Cochrane $(n=4) \quad$ Elsevier $(n=10)$ Wiley $(n=7)$

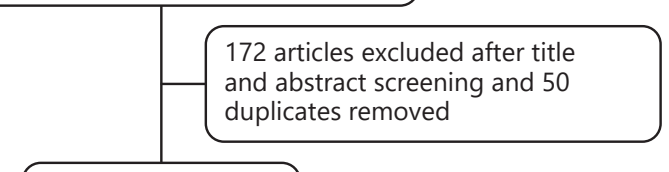

50 full texts retrieved for evaluation

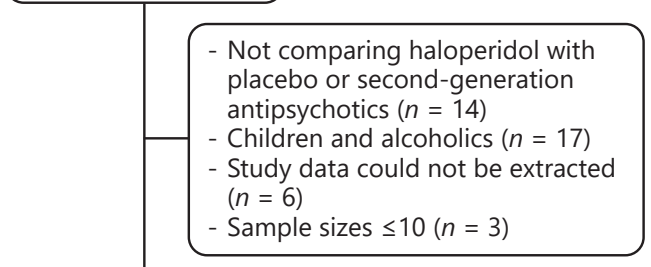

10 studies met the inclusion criteria

Fig. 1. Flowchart for study inclusion and exclusion.

Data Extraction and Quality Assessment

The following data were independently extracted by 2 reviewers (Y.S. and K.P.): first author, year of publication, study design, inclusion and exclusion criteria, interventions, number of patients, and outcomes. The primary end point was the incidence and severity of delirium. Secondary end points were the duration of delirium, mortality, length of intensive care unit (ICU) stay, length of hospital stay, and the incidence of corrected QT (QTc) interval prolongation and extrapyramidal symptoms. The severity of delirium was measured by revised Delirium Rating Scale (DRS-R98) scores, and Mini-Mental State Examination (MMSE) scores.

The methodological quality of each included study was evaluated using the Cochrane risk of bias assessment tool [24]. Disagreements on data abstraction and quality assessment were resolved by group discussion.

\section{Statistical Analysis}

All analyses were performed using Review Manager 5.3 (The Cochrane Collaboration, Copenhagen, Denmark). Dichotomous variables, including the incidence of delirium, mortality, QTc interval prolongation, and extrapyramidal symptoms, were reported as the risk ratio (RR) with $95 \%$ confidence interval (CI), while mean difference (MD) with 95\% CI was used for the continuous variables, including the duration of delirium, ICU stay, hospital stay, DRS-R98 scores, and MMSE scores. The results of risperidone and olanzapine groups were combined using the calculator in Revman [25]. A $p$ value $<0.05$ was considered statistically significant.

The heterogeneity among studies was assessed using the $I^{2}$ test. If the $I^{2}$ index was $\leq 50 \%$, the fixed-effect model was selected to 
Table 1. Characteristics of the included studies

\begin{tabular}{|c|c|c|c|c|c|}
\hline Study & Design & Inclusion criteria (setting) & Exclusion criteria & Interventions (patients, $n$ ) & Outcomes \\
\hline $\begin{array}{l}\text { Al-Qadheeb } \\
{[16], 2016}\end{array}$ & $\begin{array}{l}\text { RCT, } \\
\text { delirium prophylaxis }\end{array}$ & $\begin{array}{l}\text { Mechanically ventilated } \\
\text { patients with subsyndromal } \\
\text { delirium (ICU) }\end{array}$ & $\begin{array}{l}\text { Age } \geq 85 \text { years, safety concerns } \\
\text { associated with haloperidol, } \\
\text { condition might preclude delirium } \\
\text { evaluation, admitted to ICU for } \geq 4 \\
\text { days }\end{array}$ & $\begin{array}{l}\text { Haloperidol }(n=34): 1 \mathrm{mg} \\
\text { every } 6 \mathrm{~h} \text { until delirium } \\
\text { occurred, } 10 \text { days of therapy } \\
\text { elapsed, or ICU discharge } \\
\text { Placebo }(n=34): 5 \% \text { dextrose }\end{array}$ & $\begin{array}{l}\text { Incidence of delirium, } \\
\text { delirium-related outcomes, } \\
\text { QTc interval prolongation, } \\
\text { extrapyramidal symptoms, } \\
\text { ICU stay, ICU disposition, } \\
\text { hospital disposition }\end{array}$ \\
\hline $\begin{array}{l}\text { Fukata [17], } \\
2014\end{array}$ & $\begin{array}{l}\text { Randomized, open-label } \\
\text { prospective trial, } \\
\text { delirium prophylaxis }\end{array}$ & $\begin{array}{l}\text { Age } \geq 75 \text { years, scheduled for } \\
\text { elective abdominal or } \\
\text { orthopedic surgery } \\
\text { (surgical) }\end{array}$ & $\begin{array}{l}\text { Emergency surgery, delirium, use } \\
\text { of antipsychotics, antidepressants, } \\
\text { hypnotics or anti-Parkinson agents } \\
\text { within } 2 \text { weeks before surgery }\end{array}$ & $\begin{array}{l}\text { Haloperidol }(n=59): 2.5 \mathrm{mg} \\
\text { daily for } 3 \text { days after surgery } \\
\text { Placebo }(n=60) \text { : details not } \\
\text { mentioned }\end{array}$ & $\begin{array}{l}\text { NEECHAM scores, } \\
\text { postoperative delirium, } \\
\text { duration of delirium }\end{array}$ \\
\hline $\begin{array}{l}\text { Fukata [14], } \\
2017\end{array}$ & $\begin{array}{l}\text { Randomized, open-label } \\
\text { prospective trial, } \\
\text { delirium prophylaxis }\end{array}$ & $\begin{array}{l}\text { Age } \geq 75 \text { years, scheduled for } \\
\text { elective abdominal or } \\
\text { orthopedic surgery } \\
\text { (surgical) }\end{array}$ & $\begin{array}{l}\text { Emergency surgery, delirium, use } \\
\text { of antipsychotics, antidepressants, } \\
\text { hypnotics or anti-Parkinson agents } \\
\text { within } 2 \text { weeks before surgery }\end{array}$ & $\begin{array}{l}\text { Haloperidol }(n=101): 5 \mathrm{mg} \\
\text { daily for } 5 \text { days after surgery } \\
\text { Placebo }(n=100) \text { : details not } \\
\text { mentioned }\end{array}$ & $\begin{array}{l}\text { NEECHAM scores, } \\
\text { postoperative delirium, } \\
\text { duration of delirium }\end{array}$ \\
\hline $\begin{array}{l}\text { Grover [27], } \\
2011\end{array}$ & $\begin{array}{l}\mathrm{RCT}, \\
\text { delirium treatment }\end{array}$ & $\begin{array}{l}\text { Age }>18 \text { years, diagnosis of } \\
\text { delirium (not mentioned) }\end{array}$ & $\begin{array}{l}\text { Alcohol or benzodiazepine } \\
\text { withdrawal, dementia, terminal } \\
\text { illness, comorbid psychotic or } \\
\text { mood disorders }\end{array}$ & $\begin{array}{l}\text { Haloperidol }(n=21) \\
0.25-5 \mathrm{mg} / \text { day } \\
\text { Risperidone }(n=20) \\
0.5-2 \mathrm{mg} / \text { day } \\
\text { Olanzapine }(n=23): \\
1.25-10 \mathrm{mg} / \text { day }\end{array}$ & $\begin{array}{l}\text { DRS-R98 scores, MMSE scores, } \\
\text { side effects }\end{array}$ \\
\hline $\begin{array}{l}\text { Grover [25], } \\
2016\end{array}$ & $\begin{array}{l}\text { RCT, } \\
\text { delirium treatment }\end{array}$ & $\begin{array}{l}\text { Age }>18 \text { years, diagnosis of } \\
\text { delirium (not mentioned) }\end{array}$ & $\begin{array}{l}\text { Alcohol or benzodiazepine } \\
\text { withdrawal, dementia, terminal } \\
\text { illness, comorbid psychotic or } \\
\text { mood disorders }\end{array}$ & $\begin{array}{l}\text { Haloperidol }(n=32): \\
0.25-1.25 \mathrm{mg} / \text { day } \\
\text { Quetiapine }(n=31): \\
12.5-75 \mathrm{mg} / \text { day }\end{array}$ & $\begin{array}{l}\text { DRS-R98 scores, MMSE scores, } \\
\text { side effects }\end{array}$ \\
\hline $\begin{array}{l}\text { Kalisvaart } \\
{[12], 2005}\end{array}$ & $\begin{array}{l}\text { RCT, } \\
\text { delirium prophylaxis }\end{array}$ & $\begin{array}{l}\text { Age } \geq 70 \text { years, scheduled for } \\
\text { hip surgery (surgical) }\end{array}$ & $\begin{array}{l}\text { Delirium, haloperidol allergy, use } \\
\text { of cholinesterase inhibitors, } \\
\text { Parkinson, epilepsy, or levodopa } \\
\text { treatment, inability to participate } \\
\text { in interviews, delay of surgery, QTc } \\
\text { prolongation }\end{array}$ & $\begin{array}{l}\text { Haloperidol }(n=212): 1.5 \mathrm{mg} / \\
\text { day for } 3 \text { days after surgery } \\
\text { Placebo }(n=218) \text { : identical in } \\
\text { appearance }\end{array}$ & $\begin{array}{l}\text { Incidence of delirium, } \\
\text { DRS-R98 score, duration of } \\
\text { delirium, hospital stay }\end{array}$ \\
\hline $\begin{array}{l}\text { Kaneko [13], } \\
1999\end{array}$ & $\begin{array}{l}\text { RCT, } \\
\text { delirium prophylaxis }\end{array}$ & $\begin{array}{l}\text { Scheduled for elective } \\
\text { gastrointestinal surgery } \\
\text { (surgical) }\end{array}$ & Not mentioned & $\begin{array}{l}\text { Haloperidol }(n=38): 5 \mathrm{mg} \text { for } \\
5 \text { days after surgery } \\
\text { Placebo }(n=40) \text { : normal saline }\end{array}$ & $\begin{array}{l}\text { Incidence of delirium, use of } \\
\text { pain medication, sleep pattern }\end{array}$ \\
\hline $\begin{array}{l}\text { Page [19], } \\
2013\end{array}$ & $\begin{array}{l}\text { RCT, } \\
\text { delirium prophylaxis }\end{array}$ & $\begin{array}{l}\text { Age } \geq 18 \text { years, needing } \\
\text { mechanical ventilation } \\
\text { within } 72 \mathrm{~h} \text { of admission } \\
\text { (ICU) }\end{array}$ & $\begin{array}{l}\text { Allergy to haloperidol, moderate to } \\
\text { severe dementia, Parkinson } \\
\text { disease, structural brain damage, } \\
\text { chronic antipsychotic use }\end{array}$ & $\begin{array}{l}\text { Haloperidol }(n=71): 2.5 \mathrm{mg} \\
\text { every } 8 \mathrm{~h} \text {, irrespective of coma } \\
\text { or delirium status } \\
\text { Placebo }(n=70): 0.9 \% \text { saline }\end{array}$ & $\begin{array}{l}\text { Delirium-free and coma-free } \\
\text { days in first } 14 \text { days after } \\
\text { randomization, delirium-free } \\
\text { and coma-free days to day } 28, \\
\text { ventilator-free days to day } 28, \\
\text { mortality at } 28 \text { days, length of } \\
\text { critical care, hospital stay, } \\
\text { adverse effects }\end{array}$ \\
\hline $\begin{array}{l}\text { Schrøder } \\
\text { Pedersen [18], } \\
2013\end{array}$ & $\begin{array}{l}\text { Prospective } \\
\text { interventional cohort } \\
\text { study, } \\
\text { delirium prophylaxis }\end{array}$ & $\begin{array}{l}\text { Age } \geq 18 \text { years, scheduled for } \\
\text { open cardiac surgery with } \\
\text { cardiopulmonary bypass } \\
\text { (surgical) }\end{array}$ & $\begin{array}{l}\text { Death or transfer to another } \\
\text { department within } 24 \mathrm{~h} \text { after } \\
\text { surgery, coma or heavy sedation } \\
\text { throughout the admission }\end{array}$ & $\begin{array}{l}\text { Haloperidol }(n=123): 2.5-5 \\
\text { mg orally, } 3 \text { times a day for } 1.5 \\
\text { days, then tapered over } 2 \text { days } \\
\text { Placebo }(n=117) \text { : details not } \\
\text { mentioned }\end{array}$ & $\begin{array}{l}\text { Incidence, onset, and duration } \\
\text { of postcardiotomy delirium, } \\
\text { proportion of delirium- and } \\
\text { coma-free days, length of stay, } \\
\text { all-cause complications, } \\
\text { 180-day mortality }\end{array}$ \\
\hline $\begin{array}{l}\text { Wang [15], } \\
2012\end{array}$ & $\begin{array}{l}\text { RCT, } \\
\text { delirium prophylaxis }\end{array}$ & $\begin{array}{l}\text { Age } \geq 70 \text { years, admitted to } \\
\text { ICU after noncardiac } \\
\text { surgery (surgical and ICU) }\end{array}$ & $\begin{array}{l}\text { History of schizophrenia, epilepsy, } \\
\text { parkinsonism, use of cholinesterase } \\
\text { inhibitor or levodopa treatment, } \\
\text { inability to communicate }\end{array}$ & $\begin{array}{l}\text { Haloperidol }(n=229): 0.5 \mathrm{mg} \\
\text { followed by continuous } \\
\text { infusion of } 0.1 \mathrm{mg} / \mathrm{h} \text { for } 12 \mathrm{~h} \\
\text { Placebo }(n=228) \text { : normal } \\
\text { saline }\end{array}$ & $\begin{array}{l}\text { Incidence of delirium during } \\
\text { the first } 7 \text { days after surgery, } \\
\text { safety and tolerability of } \\
\text { haloperidol, time to delirium } \\
\text { onset, daily prevalence of } \\
\text { delirium, number of delirium- } \\
\text { free days, ICU stay, adverse } \\
\text { effects, 28-day mortality }\end{array}$ \\
\hline
\end{tabular}

RCT, randomized controlled trial; ICU, intensive care unit; DRS-R98, Delirium Rating Scale-Revised 98; NEECHAM, Neelon and Champagne Confusion Scale; MMSE, MiniMental State Examination. 
Table 2. Risk of bias in the included studies

\begin{tabular}{|c|c|c|c|c|c|c|c|}
\hline Al-Qadheeb [16], 2016 & Low risk & Low risk & low risk & Low risk & Low risk & Low risk & Low risk \\
\hline Fukata [17], 2014 & Low risk & Unclear risk & High risk & Low risk & Low risk & Low risk & Low risk \\
\hline Fukata [14], 2017 & Low risk & Unclear risk & High risk & Low risk & Low risk & Low risk & Low risk \\
\hline Kalisvaart [12], 2005 & Low risk & Low risk & Low risk & Low risk & Low risk & Low risk & Low risk \\
\hline Kaneko [13], 1999 & Low risk & Low risk & Unclear risk & Unclear risk & Low risk & Low risk & Low risk \\
\hline Page [19], 2013 & Low risk & Low risk & Low risk & Low risk & Low risk & Low risk & Low risk \\
\hline Schrøder Pedersen [18], 2013 & High risk & High risk & High risk & Unclear risk & Low risk & Low risk & Low risk \\
\hline Wang [15], 2012 & Low risk & Low risk & Low risk & Low risk & Low risk & Low risk & Low risk \\
\hline
\end{tabular}

calculate the pooled effects; otherwise, a random-effect model was used $[24,26]$. The following sensitivity analyses were performed to test the robustness of the results: (a) whether the quality of publication (RCT or non-RCT) could influence the results, and (b) subgroup analyses according to the data of surgical versus ICU settings and high doses $(\geq 5 \mathrm{mg})$ versus low doses $(<5 \mathrm{mg})$ of haloperidol.

\section{Results}

\section{Study Selection and Characteristics}

The study characteristics are described in Table 1 . The patient populations ranged from 63 to 457 . Seven studies were RCTs, 2 were randomized, open-label prospective trials, and 1 was a prospective interventional cohort study $[12-19,25,27]$. A risk assessment of the included studies is presented in Table 2 .

\section{Haloperidol versus Placebo for Delirium Prophylaxis}

Eight studies [12-19] compared haloperidol with placebo for preventing delirium in surgical and ICU patients. Overall, haloperidol prophylaxis did not decrease the incidence of delirium compared with placebo (RR $0.84,95 \%$ CI $0.62,1.13, p=0.24, I^{2}=55 \%$; Fig. 2) [12-18]. Subgroup analysis based on surgical versus ICU patients did not detected any significance with $I^{2}=58.6 \%$ (Fig. 2a). Subgroup analysis based on haloperidol doses showed that the use of a high dose of haloperidol ( $\geq 5 \mathrm{mg} /$ day) may reduce the incidence of delirium (RR $0.50,95 \%$ CI $0.32,0.79, p=0.003, I^{2}=0 \%$; Fig. $2 \mathrm{~b}$ ). Of the 8 studies, 5 $[12,16-19]$ showed that haloperidol prophylaxis did not shorten the duration of delirium (MD - 0.75 days, $95 \%$ CI $-1.97,0.46, p=0.22, I^{2}=84 \%$; Fig. 3a).

In the sensitivity analyses, the $I^{2}$ index values in the outcome of delirium incidence remained above $30 \%$. Substantial heterogeneity of $I^{2}=57 \%$ was found when we included only RCTs. For the outcome of duration of delirium, substantial heterogeneity still existed $\left(I^{2}=86 \%\right)$ when only RCTs were included.

Regarding the side effects associated with haloperidol, 3 studies $[11,15,16]$ showed that there were no differences in QTc interval prolongation or the incidence of extrapyramidal symptoms (Fig. 3b, c). In addition, there were no differences in ICU stay, hospital stay, or mortality between the haloperidol and placebo groups (Fig. 4).

\section{Haloperidol versus Second-Generation Antipsychotics for Delirium Treatment}

For delirium treatment, no difference was found in DRS-R98 or MMSE scores at 0,3 , and 6 days between the haloperidol and second-generation antipsychotics treatment groups (Fig. 5, 6) [24, 26].

\section{Discussion}

This systematic review and meta-analysis suggests that a high dose ( $\geq 5 \mathrm{mg} /$ day) of haloperidol prophylaxis might help reduce delirium in surgical patients. However, use of haloperidol did not influence the duration of delirium, QTc interval prolongation, extrapyramidal symptoms, ICU stay, hospital stay, or mortality. For delirium 


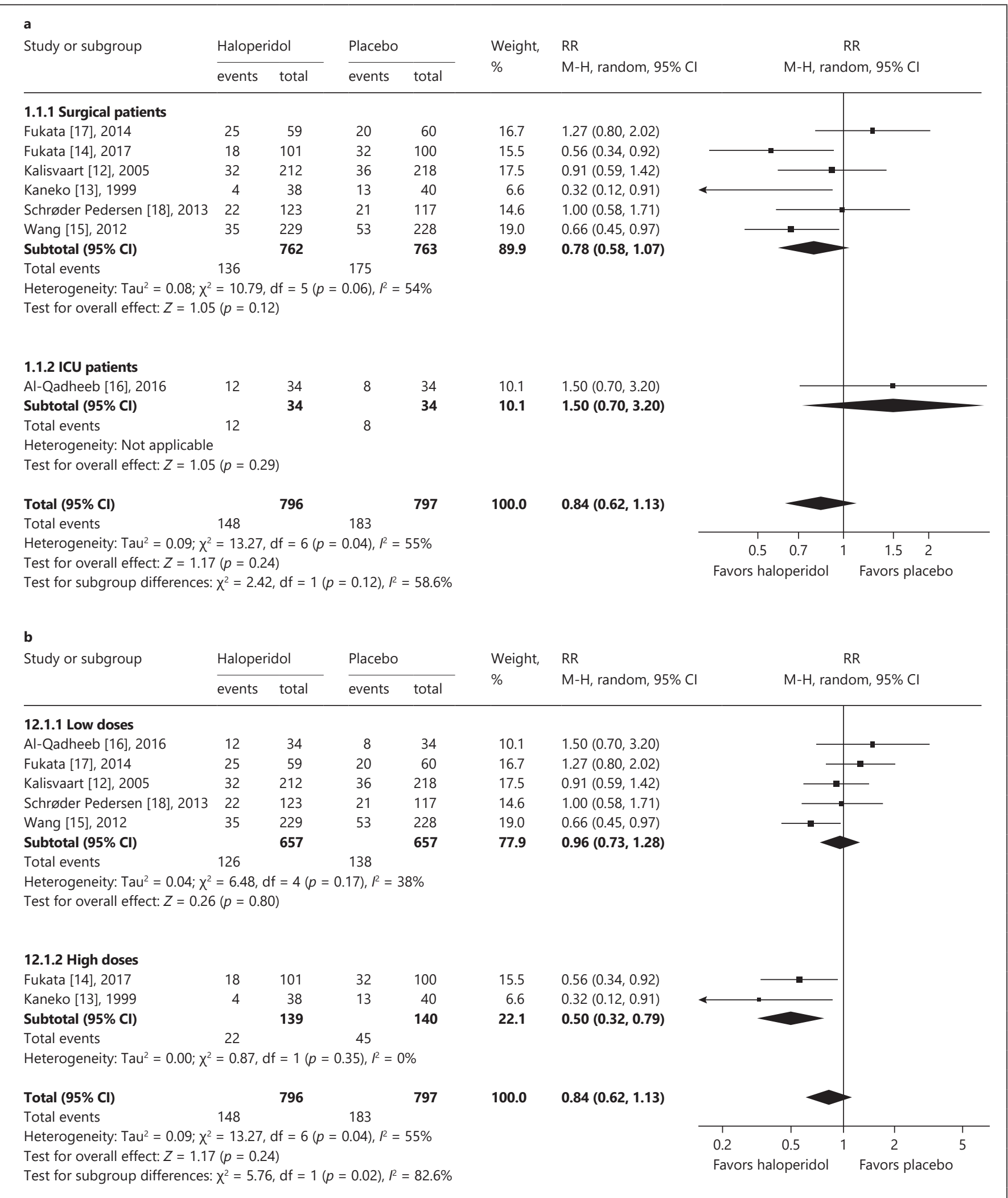

Fig. 2. Meta-analysis of haloperidol versus placebo for the incidence of delirium: surgical patients versus ICU patients (a), low versus high dose (b). 


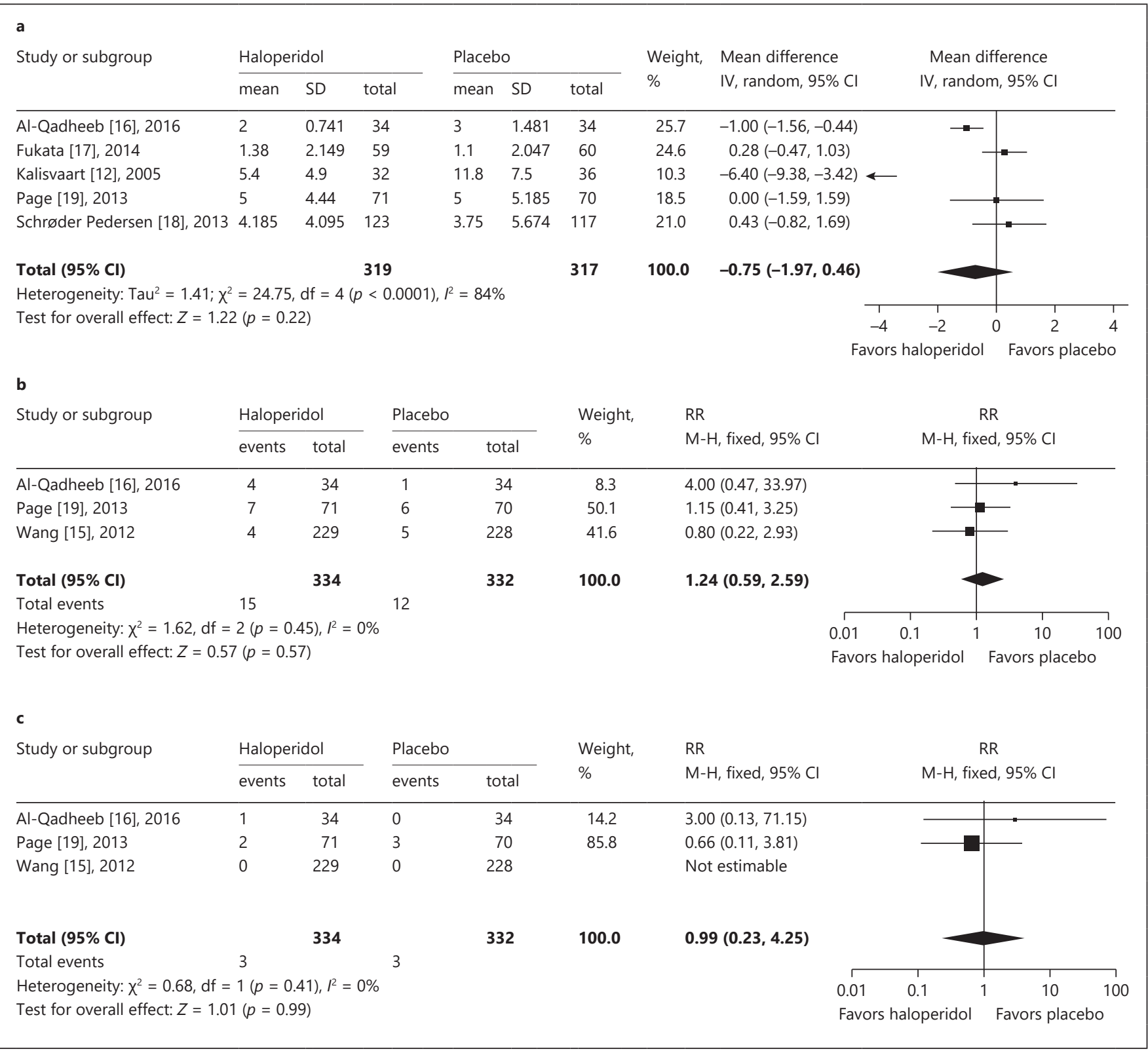

Fig. 3. Meta-analysis of haloperidol versus placebo for duration of delirium (a), QTc interval prolongation (b), and extrapyramidal symptoms (c).

treatment, haloperidol had similar therapeutic effects on MMSE and DRS-R98 scores as the second-generation antipsychotics.

Subgroup analysis showed that a high dose of haloperidol ( $\geq 5 \mathrm{mg}$ /day) reduced the incidence of delirium in surgical patients. However, more evidence is needed due to the limited number of studies included for this out- come. Kalisvaart et al. [12] used a small dose of haloperidol ( $1.5 \mathrm{mg} /$ day $)$ and found no difference in delirium outcomes between the groups. Wang et al. [15] also used a small dose $(0.5 \mathrm{mg}$ intravenous bolus injection followed by continuous infusion of $0.1 \mathrm{mg} / \mathrm{h}$ for $12 \mathrm{~h}$ ) and reported a lower incidence of delirium in the haloperidol group, suggesting that continuous infusion may be a better 


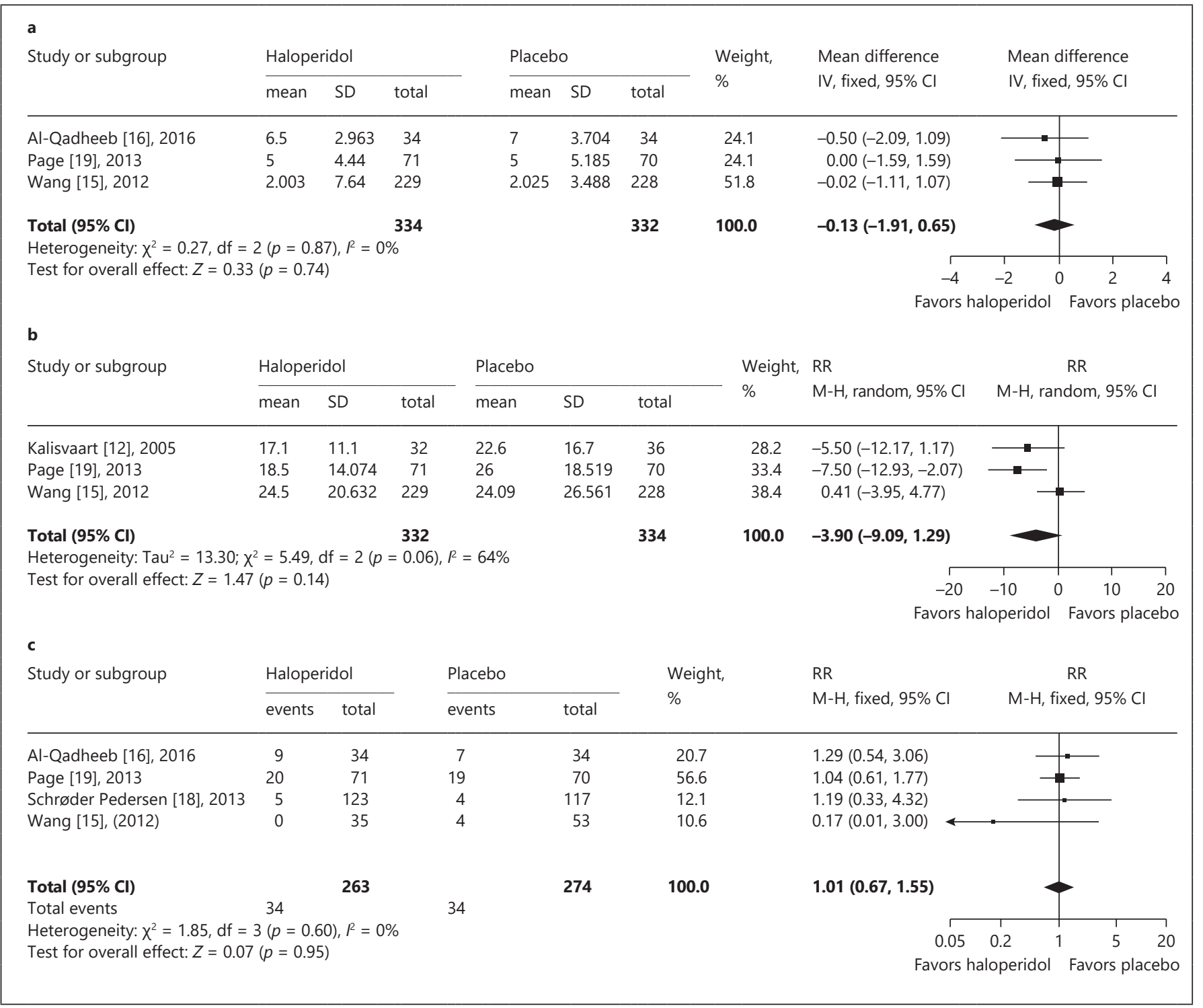

Fig. 4. Meta-analysis of haloperidol versus placebo for ICU stay (a), hospital stay (b), and mortality (c).

choice. Besides, initiating the therapeutic intervention as early as possible by detecting the early signs of delirium is essential for preventing its aggravation. With regard to the early stage of postoperative delirium, a concept exists called "subsyndromal delirium" [28-31], which is a frequent and clinically important condition that falls on a continuum between no symptoms and full delirium. The importance of starting the prophylactic intervention during the subsyndromal stage has also been reported. Hakim et al. [32] showed that early treatment with risperi- done during the subsyndromal phase had a preventative effect against postoperative delirium after on-pump cardiac surgery in the elderly.

A higher dose of haloperidol may cause a higher incidence of side effects. In the study by Page et al. [19] the incidences of QTc interval prolongation and extrapyramidal symptoms in the haloperidol group were 9.86 and $2.82 \%$, respectively, compared to 1.75 and $0 \%$ in the study by Wang et al. [15] with a low dose of $1.7 \mathrm{mg} /$ day. Currently, a dose of 3-5 mg/day of haloperidol is suggested, 


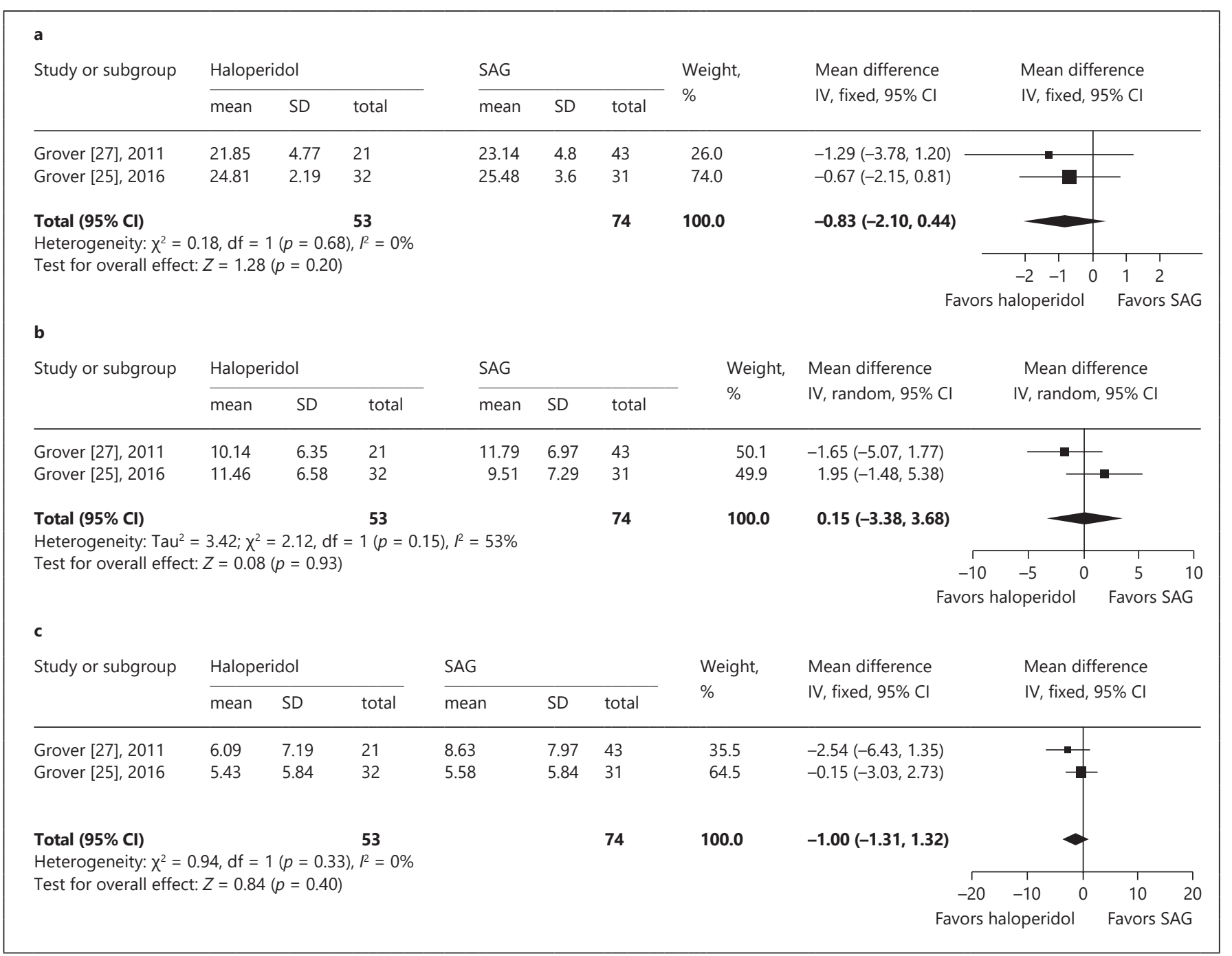

Fig. 5. Meta-analysis of haloperidol versus SGA for DRS-R98 scores at 0 (a), 3 (b), and 6 (c) days. SGA, secondgeneration antipsychotics.

but the therapy for delirium still needs be tailored to the characteristics of each individual [33-35].

The limitations of this study include the fact that a small number of studies met the inclusion criteria, hence the sample size was relatively small. Further limitations were the heterogeneity of the included studies, the fact that other medications such as dexmedetomidine were reported to have aided in the reduction of postoperative delirium, and the lack of a placebo group for the comparison of haloperidol with second-generation antipsychotics for delirium treatment.

\section{Conclusion}

In this systematic review and meta-analysis, haloperidol prophylaxis with a dose of $\geq 5 \mathrm{mg}$ /day might help reduce the incidence of delirium in surgical patients. For the treatment of delirium, haloperidol exhibited similar effects as the second-generation antipsychotics. However, more studies are required to investigate the optimal regimen for the prophylaxis and treatment of delirium in high-risk patients. 


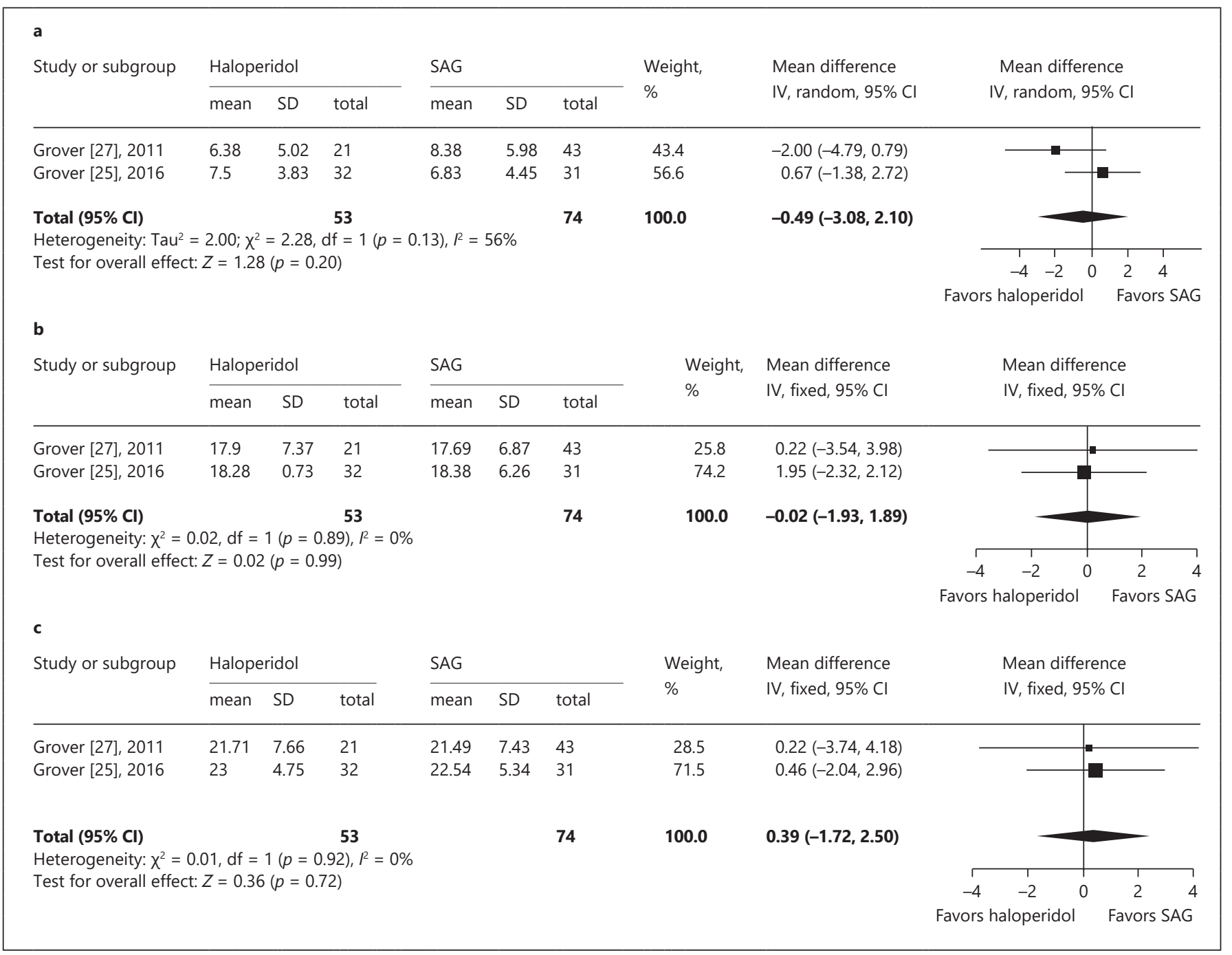

Fig. 6. Meta-analysis of haloperidol versus SGA for MMSE scores at 0 (a), 3 (b), and 6 (c) days. SGA, secondgeneration antipsychotics.

\section{Acknowledgement}

This work was supported, in part, by grants from the National Natural Science Foundation of China (81471835 and 81671880 to F.J., 81601666 to J.Z., and 81601659 to K.P.).

\section{Disclosure Statement}

The authors have no conflicts of interest to declare.
References

Med Princ Pract

DOI: $10.1159 / 000488243$
1 American Psychiatric Association: Diagnostic and Statistical Manual of Mental Disorders (DSM-IV) ed 4. Washington, American Psychiatric Association, 2000, pp 27-50.

2 Ely EW, Shintani A, Truman B, et al: Delirium as a predictor of mortality in mechanically ventilated patients in the intensive care unit. JAMA 2004;291:1753-1762.

- 3 Inouye SK, Westendorp RG, Saczynski JS: Delirium in elderly people. Lancet 2014;383: 911-922.

-4 Ryan DJ, O’Regan NA, Caoimh RÓ, et al: Delirium in an adult acute hospital population: predictors, prevalence and detection. BMJ Open 2013;3:e001772. 
5 Barr J, Fraser GL, Puntillo K, et al: American College of Critical Care Medicine: clinical practice guidelines for the management of pain, agitation, and delirium in adult patients in the intensive care unit. Crit Care Med 2013; 41:263-306.

6 Kalisvaart KJ, Vreeswijk R, de Jonghe JF, et al: Risk factors and prediction of postoperative delirium in elderly hip-surgery patients: implementation and validation of a medical risk factor model. J Am Geriatr Soc 2006; 54:817822.

7 Litaker D, Locala J, Franco K, et al: Preoperative risk factors for postoperative delirium. Gen Hosp Psychiatry 2001;23:84-89.

-8 Dasgupta M, Dumbrell AC: Preoperative risk assessment for delirium after noncardiac surgery: a systematic review. J Am Geriatr Soc 2006;54:1578-1589.

9 Rudolph JL, Jones RN, Rasmussen LS, et al: Independent vascular and cognitive risk factors for postoperative delirium. Am J Med 2007;120:807-813.

10 Leung JM, Sands LP, Wang Y, et al: Apolipoprotein E e4 allele increases the risk of early postoperative delirium in older patients undergoing noncardiac surgery. Anesthesiology 2007;107:406-411.

11 Echigoya Y, Kato H: Causes of postoperative delirium after abdominal surgery in elderly patients. Japan J Anesthesiol 2007;56:932936.

$\checkmark 12$ Kalisvaart KJ, de Jonghe JF, Bogaards MJ, et al: Haloperidol prophylaxis for elderly hipsurgery patients at risk for delirium: a randomized placebo-controlled study. J Am Geriatr Soc 2005;53:1658-1666.

13 Kaneko T, Cai J, Ishikura T, et al: Prophylactic consecutive administration of haloperidol can reduce the occurrence of postoperative delirium in gastrointestinal surgery. Yonago Acta Med 1999;42:179-184.

14 Fukata S, Kawabata Y, Fujisiro K, et al: Haloperidol prophylaxis for preventing aggravation of postoperative delirium in elderly patients: a randomized, open-label prospective trial. Surg Today 2017;47:815-826.
15 Wang W, Li HL, Wang DX, et al: Haloperidol prophylaxis decreases delirium incidence in elderly patients after noncardiac surgery: a randomized controlled trial. Crit Care Med 2012;40:731-739.

16 Al-Qadheeb NS, Skrobik Y, Schumaker G, et al: Preventing ICU subsyndromal delirium conversion to delirium with low-dose IV haloperidol: a double-blind, placebo-controlled pilot study. Crit Care Med 2016;44:583-591.

17 Fukata S, Kawabata Y, Fujisiro K, et al: Haloperidol prophylaxis does not prevent postoperative delirium in elderly patients: a randomized, open-label prospective trial. Surg Today 2014;44:2305-2313.

18 Schrøder Pedersen S, Kirkegaard T, Balslev Jørgensen $\mathrm{M}$, et al: Effects of a screening and treatment protocol with haloperidol on postcardiotomy delirium: a prospective cohort study. Interact Cardiovasc Thorac Surg 2013; 18:438-445.

19 Page VJ, Ely EW, Gates S, et al: Effect of intravenous haloperidol on the duration of delirium and coma in critically ill patients (HopeICU): a randomised, double-blind, placebo controlled trial. Lancet Respir Med 2013;1: 515-523.

20 Vochteloom AJ, Moerman S, van der Burg BL, et al: Delirium risk screening and haloperidol prophylaxis program in hip fracture patients is a helpful tool in identifying highrisk patients, but does not reduce the incidence of delirium. BMC Geriatr 2011;11:39.

21 Schrijver EJM, de Vries OJ, van de Ven PM, et al: Haloperidol versus placebo for delirium prevention in acutely hospitalised older at risk patients: a multi-centre double-blind randomised controlled clinical trial. Age Ageing 2018;47:48-55.

22 Schrijver EJ, de Graaf K, de Vries OJ, et al: Efficacy and safety of haloperidol for in-hospital delirium prevention and treatment: a systematic review of current evidence. Eur J Intern Med 2016;27:14-23.

23 Santos E, Cardoso D, Neves H, et al: Effectiveness of haloperidol prophylaxis in critically ill patients with a high risk of delirium: a systematic review. JBI Database System Rev Implement Rep 2017;15:1440-1472.
24 Higgins J, Green S: Cochrane handbook for systematic reviews of interventions, version 5.1.0. The Cochrane Collaboration, 2011. www.cochrane-handbook.org.

25 Grover S, Mahajan S, Chakrabarti S, et al: Comparative effectiveness of quetiapine and haloperidol in delirium: a single blind randomized controlled study. World J Psychiatry 2016;6:365-371.

26 Scholz AF, Oldroyd C, McCarthy K, et al: Systematic review and meta-analysis of risk factors for postoperative delirium among older patients undergoing gastrointestinal surgery. Br J Surg 2016;103:e21-e28.

27 Grover S, Kumar V, Chakrabarti S: Comparative efficacy study of haloperidol, olanzapine and risperidone in delirium. J Psychosom Res 2011;71:277-281.

28 Meaher D, O'Regan N, Ryan D, et al: Frequency of delirium and subsyndromal delirium in an adult acute hospital population. Br J Psychiatry 2014;205:478-485.

29 Core MG, Ciampi A, Belzile E, et al: Subsyndromal delirium in older people: a systemic review of frequency, risk factors, course and outcomes. Int J Geriatr Psychiatry 2013;28: 771-780.

30 Shim J, DePalma G, Sands LP, et al: Prognostic significance of postoperative subsyndromal delirium. Psychosomatics 2015;56:644-651.

31 Breu A, Stransky M, Metterlein T, et al: Subsyndromal delirium after cardiac surgery. Scand Cardiovasc J 2015;49:207-212.

32 Hakim SM, Othman AI, Naoum DO: Early treatment with risperidone for subsyndromal delirium after on-pump cardiac surgery in the elderly: a randomized trial. Anesthesiology 2012;116:987-997.

- 33 American Psychiatric Association: Practice guideline for the treatment of patients with delirium. Am J Psychiatry 1999;156:1-20.

- 34 Hassan E, Fontaine DK, Nearman HS: Therapeutic considerations in the management of agitated or delirious critically ill patients. Pharmacotherapy 1998;18:113-129.

35 Mahboobi N, Nolden-Hoverath S, Rieker O, et al: Multiple sclerosis presenting as a delirium: a case report. Med Princ Pract 2015;24: 388-390. 